\title{
Lansoprazole as a rescue agent in chemoresistant tumors: a phase I/II study in companion animals with spontaneously occurring tumors
}

\author{
Enrico P Spugnini ${ }^{1}$, Alfonso Baldi ${ }^{2}$, Sabrina Buglioni ${ }^{3}$, Francesca Carocci ${ }^{3}$, Giulia Milesi de Bazzichini ${ }^{4}$, \\ Gianluca Betti ${ }^{4}$, Ilaria Pantaleo ${ }^{4}$, Francesco Menicagli ${ }^{5}$, Gennaro Citro ${ }^{1}$ and Stefano Fais ${ }^{6^{*}}$
}

\begin{abstract}
Background: The treatment of human cancer has been seriously hampered for decades by resistance to chemotherapeutic drugs. Mechanisms underlying this resistance are far from being entirely known. A very efficient mechanism of tumor resistance to drugs is related to the modification of tumour microenvironment through changes in the extracellular and intracellular $\mathrm{pH}$. The acidification of tumor microenvironment depends on proton pumps that actively pump protons outside the cells, mostly to avoid intracellular acidification. In fact, we have shown in pre-clinical settings as pre-treatment with proton-pumps inhibitors (PPI) increase tumor cell and tumor responsiveness to chemotherapeutics. In this study pet with spontaneously occurring cancer proven refractory to conventional chemotherapy have been recruited in a compassionate study.

Methods: Thirty-four companion animals (27 dogs and 7 cats) were treated adding to their chemotherapy protocols the pump inhibitor lansoprazole at high dose, as suggested by pre-clinical experiments. Their responses have been compared to those of seventeen pets (10 dogs and 7 cats) whose owners did not pursue any other therapy than continuing the currently ongoing chemotherapy protocols.

Results: The drug was overall well tolerated, with only four dogs experiencing side effects due to gastric hypochlorhydria consisting with vomiting and or diarrhea. In terms of overall response twenty-three pets out of 34 had partial or complete responses (67.6\%) the remaining patients experienced no response or progressive disease however most owners reported improved quality of life in most of the non responders. On the other hand, only three animals in the control group (17\%) experienced short lived partial responses (1-3 months duration) while all the others died of progressive disease within two months.
\end{abstract}

Conclusions: high dose proton pump inhibitors have been shown to induce reversal of tumor chemoresistance as well as improvement of the quality of life in pets with down staged cancer and in the majority of the treated animals PPI were well tolerated. Further studies are warranted to assess the efficacy of this strategy in patients with advanced cancers in companion animals as well as in humans.

Keywords: chemotherapy, lansoprazole, mitoxantrone, carboplatin, proton pump

\section{Introduction}

Cancer initiation, progression, and invasion occur in a complex and dynamic microenvironment which depends on the hosts and sites where tumors develop. The response to chemotherapy by tumor cells depends on

\footnotetext{
* Correspondence: stefano.fais@iss.it

${ }^{6}$ Anti-Tumor Drug Section, Dept. of Drug Research and Medicine Evaluation, National Institute of Health (ISS), Rome, Italy

Full list of author information is available at the end of the article
}

the concentration of cytostatics accumulated within the cells. The accumulation of anticancer drugs in tumor cells is dependent on functional expression of efflux transporters, but also on the $\mathrm{pH}$ of extracellular microenvironment. However, while the role of chemotransporters in the chemoresistance of malignant tumors has been very well documented, little is known about the role of tumor acidity and mechanisms underlying tumor acidification, including proton exchangers and 
their impact on the chemosensitivity of cancer cells. Tumor cells rely on $\mathrm{H}^{+}$exchangers to relieve themselves from the dangerous protons byproduct of cancer metabolism that could trigger a cascade of lytic enzymes that ultimately would lead to self-digestion. Among these the most prominent are the vacuolar $\mathrm{H}^{+}$-ATPases (VATPases). V-ATPases are ATP dependent $\mathrm{H}^{+}$transporters that utilize the energy freed by the hydrolysis of ATP with the active transport of protons from the cytoplasm to the lumen of intracellular compartments or, if located within the cytoplasmic membrane, the extracellular compartment [1-4]. Two important physiological mechanisms of regulating V-ATPase activity in vivo are reversible dissociation of the domain carrying ATP from the proton exchanger domain and changes in coupling efficiency of proton transport and ATP hydrolysis [5-12]. Malignant tumor cells overexpress lysosomal proteins on the cell surface, with abnormal lysosomal activities, possibly involving deranged V-ATPase function $[13,14]$. The acidic tumor environment is a consequence of anaerobic glucose metabolism resulting in accumulation of acid byproducts such as lactates. This involves the upregulation of hypoxia-inducible factor $1 \alpha$ [15] or can be dependent on inadequate tumor perfusion, hypoxia secondary to disordered tumor growth or enhanced transmembrane $\mathrm{pH}$ regulation [16]. These pumps, coupled with other ion exchangers, play a paramount role in the establishment and maintenance of malignant tumor microenvironment and their action lead to the selection of more aggressive cell phenotypes able to survive in this highly hostile microenvironment.

$\mathrm{V}$-ATPases play a critical role in the maintenance of an appropriate relatively neutral intracellular $\mathrm{pH}$, and an acidic extracellular $\mathrm{pH}$ by actively excreting protons either through ion exchange mechanisms or by segregating $\mathrm{H}^{+}$within cytoplasmic organelles that are subsequently expelled [17]. It is hypothesized that the low extracellular $\mathrm{pH}$ of tumors might trigger proteases (MMP-2, MMP-9, cathepsin B, and cathepsin L), leading to the dissolution of extracellular matrix. Proton exchangers-mediated acidification of tumor microenvironment significantly contributes to tumor invasion and dissemination $[18,19]$. In fact, it has been shown that by inhibiting V-ATPases through RNA interference, it was possible to prevent cancer metastases in a murine model [19]. This could be a novel strategy to deal with the process of tumor dissemination through the increase of the extracellular tumor $\mathrm{pH}$, thus inhibiting the activation of tumor proteases. From the therapeutic point of view, the changes in the $\mathrm{pH}$ gradient occurring between the intracellular and the extracellular compartments as well as the $\mathrm{pH}$ gradient between the cytoplasm and the intracellular organelles can be significantly involved in the mechanism of drug resistance [20-22]. There are several proposed mechanisms involved in this phenomenon, including decreased uptake or neutralization of weakly basic drugs by the acidic tumor microenvironment or the confinement of chemotherapy drugs within lysosomal vesicles [21-25]. An accelerated turnover of acidic vesicles may represent an additional tumor strategy of drug resistance based on counteracting current transportation [26,27]. Interestingly, the expression of proton pumps is increased in chemoresistant phenotypes and is increased by anticancer drugs [28-31]. Investigation in xenograft models with different human tumor histologies have shown as proton pump inhibition may on one hand induce chemosensibilization, on the other hand trigger a clear tumor cytotoxicity $[26,27]$. Proton pump inhibitors are normally adopted in the treatment of gastritis, Zollinger-Ellison syndrome and, limitedly to veterinary oncology, gastric hyperacidity secondary to mast cell tumors in dogs and cats [32-36]. These drugs have been shown to be highly effective at inhibiting V-ATPases in vitro and well tolerated and extremely efficacious in murine models, resulting in increased chemotherapy efficacy and improved tumor control $[27,31,37,38]$. Moreover, according to data reported in current veterinary literature, at least in two dogs with gastrinoma, PPI therapy with omeprazole resulted in survivals in excess of 2 years. Such long survivals, are potentially more due to tumor control secondary to cancer microenvironment manipulation than to palliation of hyper acidic syndrome and prevention of gastrointestinal ulcerations $[33,35]$. Aim of this study was to investigate the feasibility, tolerability and efficacy of high dose proton pump inhibitor lansoprazole as a rescue to revert chemoresistance in companion animals affected by neoplasms non responsive to anticancer drugs.

\section{Methods}

\section{Patient selection}

Privately owned canine and feline patients with advanced neoplasms that showed progression despite chemotherapy were selected for the study. Upon tumor escape from pharmaceutical control, owners were offered three options: a) discontinuation of all therapies, b) continuation of chemotherapy alone, c) continuation of chemotherapy with the addition of high dose lansoprazole.

Previous informed consent was obtained from the owners. In order to be enrolled in the study, according to the Italian law (116/92) and the guidelines defined by the ethical committee of the National Cancer Institute " Regina Elena" of Rome, Italy, patients, staged according to the World Health Organization (WHO) grading system, were considered eligible if they fulfilled the following criteria: 
1 Normal renal function (normal serum blood urea nitrogen $[\mathrm{BUN}]$, creatinine, phosphorus, and urine specific gravity).

2 Absence of underlying life threatening diseases or other medical complications (e.g. diabetes mellitus).

3 Compliance of the owner for follow-up rechecks.

4 A presumptive life expectancy of at least four weeks.

5 Overall performance status assessed according to the modified Karnowsky system, had to be less than 3 (Table 1).

Staging process included a thorough anamnesis, physical examination, caliper or ultrasonographic measurement of the neoplasm, complete blood cell count (CBC), serum biochemistry profile, thoracic radiographs (three projections: two laterals and one ventro-dorsal), and abdominal ultrasonography. In order to confirm the diagnoses, histological re-examination of the biopsies were performed following standard protocols, using Hematoxylin/Eosin and Hematoxylin/Van Gieson stainings by one of the authors $(\mathrm{AB})$.

\section{Treatment}

Twenty-seven privately owned dogs and seven cats presented to the Regina Elena Cancer Institute with clinically chemoresistant neoplasms and were entered the proton pump inhibitors arm in the modified phase I/II study between September 2009 and April 2011. Similarly, a group of seventeen pets whose owners declined to enroll their pets in the study but chose to continue standard chemotherapy was followed as control group.

Treatment protocol in the experimental arm consisted with lansoprazolo at $5 \mathrm{mg} / \mathrm{Kg}$ SID for three consecutive days, at the time of each chemotherapy administration, to decrease tumor $\mathrm{pH}$ and increase response to therapy, followed by four days at the dose of $1 \mathrm{mg} / \mathrm{Kg}$ SID to prevent gastric hyperacidity rebound. This schedule has been chosen on the basis of previous studies on rodents and based on the currently ongoing clinical trials in humans [27].

Response to treatment in terms of toxicity and tumor response were assessed prior each therapy. At that time a physical exam and tumor measure were performed. Moreover thoracic radiographs and abdominal ultrasonography were performed every two months to check for tumor spread. Toxicity was defined as disease processes that occurred secondary to therapy and accordingly scored (table 2). In order to have the best

Table 1 Modified Kamofsky's performance criteria

\begin{tabular}{cc}
\hline Grade & Criteria \\
\hline 0 & Activity less than predisease level; able to function as acceptable pet \\
\hline 1 & Severely compromised activity; ambulatory only to point of eating, sleeping, and consistently eliminating in acceptable areas. \\
\hline 3 & Completely disabled; must be force fed; unable to defecate or urinate \\
in acceptable areas
\end{tabular}

Table 2 Modified Eastern Cooperative Oncology Group evaluation

\begin{tabular}{cc}
\hline $\begin{array}{c}\text { Toxicity/Grade } \\
\text { Signs }\end{array}$ & Duration \\
\hline Hospitalization & Days \\
\hline 0 & 0 \\
\hline 1 & 1 \\
\hline 2 & $2-3$ \\
\hline 3 & $4-5$ \\
\hline 4 & $\geq 5$ \\
\hline
\end{tabular}

\begin{tabular}{cc}
\hline Neutropenia & \\
\hline 0 & $\leq 500$ neutrophils $/ \mathrm{mL}$ \\
\hline 1 & $1,500-2,500$ neutrophils $/ \mathrm{mL}$ \\
\hline 2 & $\geq 2,500$ neutrophils $/ \mathrm{mL}$ \\
\hline 3 & $500-999$ neutrophils $/ \mathrm{mL}$ \\
\hline 4 & $1,000-1,499$ neutrophils $/ \mathrm{mL}$ \\
\hline
\end{tabular}

\begin{tabular}{cc}
\hline 4 & $1,000-1,499$ neutrophils $/ \mathrm{mL}$ \\
\hline Anorexia & None \\
\hline 0 & Inappetance \\
\hline 1 & Anorexia $\leq 3$ days duration \\
\hline 3 & Anorexia $>3$ days but $<5$ days \\
\hline 4 & Anorexia $\geq 5$ days $10 \%$ weight loss \\
\hline
\end{tabular}

\begin{tabular}{cc}
\hline Vomiting & None \\
\hline 0 & Nausea \\
\hline 1 & Sporadic, self-limiting \\
\hline 2 & $1-5$ episodes per day, $<2$ days \\
\hline 3 & $6-10$ episodes per day, hospitalized \\
\hline 4 & None \\
\hline Diarrhea & Soft stools, responds to dietary modification \\
\hline 0 & 1-4 watery stools per day, $<2$ days \\
\hline 1 & $4-7$ watery stools per day or $>2$ days \\
\hline 2 & $>7$ watery stools per day or bloody, \\
\hline 3 & hospitalized
\end{tabular}

\begin{tabular}{cc}
\hline Infection & \\
\hline 0 & None \\
\hline 1 & No medication \\
\hline 2 & Required medication \\
\hline 3 & Debilitating \\
\hline 4 & Threatening \\
\hline
\end{tabular}


assessment of therapy toxicoses, after every therapy owners were sent home with a questionnaire to be completed in order to record possible gastrointestinal side effects of the protocol (Table 3). Tumor response was defined as follows:

Complete Remission (CR) - the disappearance of all evidence of cancer in all sites for a defined period of time.

Partial Remission (PR) - the decrease in size of all tumors by $50 \%$ or greater as measured by the sum of the product of two diameters of each tumor for a defined period of time.

Stable Disease (SD) - the decrease of $<50 \%$ or an increase of $<25 \%$ in the sum of the product of two diameters for a defined period of time.

Progressive Disease (PD) - the increase of $25 \%$ or more in the sum of the product of two diameters for a defined period of time.

No evidence of disease - absence of tumor growth (local recurrence or distant metastases) after PPI and chemotherapy for a defined period of time.

Finally, the owners were questioned prior to each therapy on the activity level, performance status and food and water consumption of their animals. Treatment were scheduled to be continued for six additional months in lymphoma patients, upon achievement of complete remission and for 3 additional months in patients with solid tumors.

\section{Results}

\section{Dogs}

PPI COHORT: Twenty-seven dogs entered the study over a 19 months period and their characteristics and treatment protocols are summarized in tables 4, 5 and 6. There were 8 mixed breed dogs, 4 Boxers, 3 West Highland White Terriers, and one each of the following breeds: Great Dane, Bull Mastiff, Bull dog, Schnauzer, Husky, Labrador, Rottweiler, German Shepherd, Argentine Dogo, Setter, Poodle, and Beagle. There were 16 males and 11 females (all of them spayed). The age ranged from 5 to 15 years with a mean a mode of 10 years. There were eleven cases of lymphoma, three of osteosarcoma, three of mammary carcinoma, two of bladder carcinoma, and finally, one each of the following: acute lymphocytic leukemia, hemangiosarcoma, anal sac carcinoma, melanoma, fibrosarcoma, oral squamous cell carcinoma, nasal carcinoma, mammary carcinosarcoma. All the patients had previous treatment with chemotherapy: lymphoma patients had been previously treated with first and rescue protocols (Madison Wisconsin or COP and upon failure, rescue with MOPP. Protocols details are provided in tables 4 and 5). Upon failure they were treated with reinstituted MOPP coupled with PPI. Only exception a patient with cutaneous lymphoma who developed intolerance to vincristine and, in consideration of its reduced cardiac fraction shortening, was treated with the doxorubin analogue mitoxantrone, coupled

Table 3 Daily evaluation form sent home and made out by the owners

\begin{tabular}{|c|c|c|c|c|}
\hline Vomiting & & & & \\
\hline \multirow[t]{3}{*}{ None } & 3 episodes per day & 5 episodes per day & $>5$ episodes per day & $>5$ per day OR \\
\hline & $\mathrm{OR}$ & $\mathrm{OR}$ & OR & days lasting $>4$ days and \\
\hline & vomiting lasting 2 days & vomiting lasting 4 days & for $>4$ days & life threatening \\
\hline \multicolumn{5}{|l|}{ Diarrhea } \\
\hline \multirow[t]{2}{*}{ None } & 2 more stools & 6 more stools & $>6$ more stools & $>6$ and life \\
\hline & than normal & than normal & than normal & hospitalized \\
\hline \multicolumn{5}{|l|}{ Nausea } \\
\hline \multirow[t]{2}{*}{ None } & Appetite loss with & Salivating or lip & Salivation or lip & Salivation/ lip \\
\hline & normal eating habits & smacking for $12 \mathrm{hrs}$ & smacking for $24 \mathrm{hrs}$ & smacking $>24 \mathrm{~h}$ \\
\hline \multicolumn{5}{|l|}{ Appetite } \\
\hline \multirow[t]{4}{*}{ Normal } & With treats or diet & Appetite loss for 3 days OR & Appetite loss for 5 days OR & Loss $>5$ days \\
\hline & change, ate $100 \%$ & With treats or diet & With treats or diet & OR \\
\hline & & change, ate $50 \%$ of normal & change, ate few bites & No interest, \\
\hline & & & & no appetite \\
\hline \multicolumn{5}{|c|}{ Flatulence } \\
\hline Normal & 1-2 episodes per day & 2-4 episodes per day & 4-6 episodes per day & $>6$ episodes per day \\
\hline \multicolumn{5}{|l|}{ Activity } \\
\hline \multirow[t]{2}{*}{ Normal } & Mild lethargy & Moderate lethargy, difficulty & Severe lethargy, only & Unable to \\
\hline & & with daily activities & gets up to go outside & rise on own \\
\hline
\end{tabular}


Table 4 Madison Wisconsin lymphoma protocol

\begin{tabular}{|c|c|c|}
\hline Week 1: & Start antacids: & $\begin{array}{c}\text { Vincristine } 0.7 \mathrm{mg} / \mathrm{m}^{2} \mathrm{IV} \\
\text { Asparaginase } 400 \mathrm{IU} / \mathrm{kg} \mathrm{IM} \\
\text { Pre-med with chlorphenamine: small-medium 2.5- } \\
5 \mathrm{mg} \mathrm{IM} \text {; medium-large } 5-10 \mathrm{mg} \mathrm{IM} \\
\text { Prednisolone } 2 \mathrm{mg} / \mathrm{kg} \text { PO SID } \\
\text { zantac } 2 \mathrm{mg} / \mathrm{kg} \mathrm{PO} \mathrm{BID} \\
\text { antepsin }<20 \mathrm{~kg} 500 \mathrm{mg},>20 \mathrm{~kg} 1-2 \mathrm{~g} \text { PO TID }\end{array}$ \\
\hline Week 2: & Stop antacids: & $\begin{array}{c}\text { Cyclophosphamide } 250 \mathrm{mg} / \mathrm{m}^{2} \text { PO or IV (+ NaCl) } \\
\text { Prednisolone } 1.5 \mathrm{mg} / \mathrm{kg} \text { PO SID } \\
\text { after week } 2\end{array}$ \\
\hline Week 3: & & $\begin{array}{c}\text { Vincristine } 0.7 \mathrm{mg} / \mathrm{m}^{2} \mathrm{IV} \\
\text { Prednisolone } 1 \mathrm{mg} / \mathrm{kg} \text { PO SID }\end{array}$ \\
\hline Week 4: & & $\begin{array}{c}\text { Doxorubicin } 30 \mathrm{mg} / \mathrm{m}^{2} \mathrm{IV}(+0.9 \% \mathrm{NaCl}) \\
\text { Pre-med with chlorphenamine and } \\
\text { metoclopramide } 0.5-1 \mathrm{mg} / \mathrm{kg} \mathrm{IM} / \mathrm{SC} \text { ) } \\
\text { Prednisolone } 0.5 \mathrm{mg} / \mathrm{kg} \text { PO SID }\end{array}$ \\
\hline Week 6: & & Vincristine $0.7 \mathrm{mg} / \mathrm{m}^{2} \mathrm{IV}$ \\
\hline Week 7: & & Cyclophosphamide $250 \mathrm{mg} / \mathrm{m}^{2} \mathrm{PO}$ or IV (+ NaCl) \\
\hline Week 8: & & Vincristine $0.7 \mathrm{mg} / \mathrm{m}^{2} \mathrm{IV}$ \\
\hline Week 9: & & $\begin{array}{c}\text { Doxorubicin } 30 \mathrm{mg} / \mathrm{m}^{2} \mathrm{IV}(+0.9 \% \mathrm{NaCl}) \\
\text { Pre-med with chlorphenamine }+ \text { metoclopramide }\end{array}$ \\
\hline Week 11: & & Vincristine $0.7 \mathrm{mg} / \mathrm{m}^{2} \mathrm{IV}$ \\
\hline Week 13: & & Cyclophosphamide $250 \mathrm{mg} / \mathrm{m}^{2} \mathrm{PO}$ or IV (+ NaCl) \\
\hline Week 15: & & Vincristine $0.7 \mathrm{mg} / \mathrm{m}^{2} \mathrm{IV}$ \\
\hline Week 17: & & $\begin{array}{c}\text { Doxorubicin } 30 \mathrm{mg} / \mathrm{m}^{2} \mathrm{IV}(+0.9 \% \mathrm{NaCl}) \\
\text { Pre-med with chlorphenamine + metoclopramide }\end{array}$ \\
\hline Week 19: & & Vincristine $0.7 \mathrm{mg} / \mathrm{m}^{2} \mathrm{IV}$ \\
\hline Week 21: & & Cyclophosphamide $250 \mathrm{mg} / \mathrm{m}^{2} \mathrm{PO}$ or IV (+ NaCl) \\
\hline Week 23: & & Vincristine $0.7 \mathrm{mg} / \mathrm{m}^{2} \mathrm{IV}$ \\
\hline Week 25: & & $\begin{array}{c}\text { Doxorubicin } 30 \mathrm{mg} / \mathrm{m}^{2} \mathrm{IV}(+0.9 \% \mathrm{NaCl}) \\
\text { Pre-med with chlorphenamine + metoclopramide }\end{array}$ \\
\hline
\end{tabular}

\section{BLOODS:}

Haematology: prior to each dose

Urine:- Dipstick after every cyclophosphamide dose

- Full urinalysis after week 7

CARDIAC SCAN:

At time of: - First doxorubicin dose

- Last doxorubicin dose

- 3 months post protocol completion

REPEAT VISITS:

If in complete remission, checks should be made at months 1, 2, 3 and 6NOTES:

- For dogs $<10 \mathrm{Kg}$, use a $1 \mathrm{mg} / \mathrm{Kg}$ dose of doxorubicin.

- All treatment is discontinued after week 25 if in complete remission.

- If neutrophil count is $<3 \times 10^{9} / \mathrm{L}$ wait 5-7 days and repeat haematology before giving chemo.

- If sterile haemorrhagic cystitis occurs on cyclophosphamide, discontinue and substitute Chlorambucil (1.4 mg/kg PO) for subsequently scheduled

cyclophosphamide injections.

- You can administer L-asparaginase (400 IU/kg IM) with each vincristine injection until CR is achieved.

with PPI. Dogs with solid tumors who had been treated with a variable number of cycles of platinum drugs and/ or anthracyclines (or their synthetic analogue mitoxantrone), were treated, upon tumor progression, with mitoxantrone in association with PPI. The only exceptions were a patient affected by vesical transitional cell carcinoma whose owners elected to be treated with piroxicam alone, because of financial issues, and three dogs with osteosarcoma whose tumor type is not responsive to veterinary adopted chemotherapy regimens that were treated with the calcifying agent clodronate. Upon failure, clodronate has been reinstituted with high dose 
Table 5 MOPP lymphoma protocol

\begin{tabular}{ccc}
\hline DAY & DRUG & DOSE \\
\hline 0 & Mechlorethamine & $3.0 \mathrm{mg} / \mathrm{m}^{2}$ \\
& Vincristine & $0.75 \mathrm{mg} / \mathrm{m}^{2}$ \\
& Procarbazine & $50 \mathrm{mg} / \mathrm{m}^{2} \mathrm{PO} \mathrm{SIDx} 14$ days \\
& Prednisone & $30 \mathrm{mg} / \mathrm{m}^{2} \mathrm{PO} \mathrm{SID} \times 14$ days \\
\hline 7 & Mechlorethamine & $3.0 \mathrm{mg} / \mathrm{m}^{2}$ \\
& Vincristine & $0.75 \mathrm{mg} / \mathrm{m}^{2}$ \\
\hline
\end{tabular}

Repeat on day 28, complete blood cell count on days $0,7,28$ etc.

PPI. In table 6 are summarized the data on the PPI cohort.

CONTROL COHORT: ten dogs were treated just with conventional chemotherapy during the study and their characteristics and therapies are summarized in table 7 . There were 3 mixed breed dogs and one each of the following breeds: Setter, Boxer, Labrador, German Shepherd, Argentine Dogo, West Higland White Terrier and Rottweiler. Overall there were 5 lymphoma patients, one with acute lymphocytic leukemia, one with cutaneous carcinoma, one with liposarcoma and two affected by mammary carcinoma. All failed their therapies at different times but the owners elected to pursue additional chemotherapies without chemosensitizers.

TOXICITY: Twenty-three dogs tolerated the dose of lansoprazole without need of reduction or discontinuation. Four dogs experienced grade 1 and two dogs had grade 2 gastrointestinal toxicity (diarrhea) that was managed with probiotics. Five dogs had flatulence (grade 1$3)$. One dog had grade 3 vomiting that required lansoprazole dose reduction (from 5 to $3 \mathrm{mg} / \mathrm{kg}$ ). Three dogs had to be withdrawn due to lansoprazole intolerance. Hematological toxicity of chemotherapy was not worsened by the addition of PPI, being limited to two episodes of grade 1 neutropenia and one case of grade 2 neutropenia that did not require treatment. Seven out of ten controls experienced progressive anemia and neutrophilia with left shift due to poor responses to therapy or progressive disease.

EFFICACY: In terms of efficacy nineteen out of twenty-eight dogs experienced various degrees of response lasting from two to twelve months, these responses were more evident in dogs affected by lymphoma (9 out 11). A paradigmatic example is shown in Figure 1, depicting the complete regression of a necrotic lymphomatous ulcer upon addition of PPI to the chemotherapy regimen of a dog with refractory lymphoma. In osteosarcoma patients the efficacy consisted in potentiation of clodronate efficacy in dogs with progressive disease that resulted in 2 partial responses. An additional benefit, beside the arrest of tumor progression has been a significant improvement of their Karnofsky performance status, characterized by a significant decrease of the pain perception shown by a better weight bearing condition and weight gain. In dogs with melanoma, carcinoma and sarcoma the addition of lansoprazole resulted in high response rates as shown by table 6 with one melanoma patient that died of thoracic lymphosarcoma while still in remission for the melanocytic tumor.

Besides the osteosarcoma patients, two other dogs with advanced disease (one affected by acute lymphocytic leukemia and one by lymphoma) with a poor Karnofsky performance status, upon clinical response, moved to a lower grade condition (one moved from grade 3 to grade 1 , the other from grade 2 to grade 1 ). On the contrary, only two dogs in the control group benefited from the continuation of chemotherapy, experiencing short lived partial responses (complete responses were not documented) while the others had progressive disease that ultimately resulted in their death. Upon questioning, all the owners reported a decreased/poor quality of life for their pets.

\section{Cats}

PPI COHORT: Seven cats entered the study during the enrollment period, their characteristics and treatment schedules are summarized in table 8 . All of them where Domestic Short Hair cats, four were females and three were males, age ranged from 7 to 12 years. Tumor types included three oral squamous cell carcinomas, two lymphomas, one fibrosarcoma and one breast carcinoma that failed chemotherapy or various combinations of surgery and chemotherapy. Upon recurrence or progressive disease, PPI inhibitor lansoprazole has been added to the chemotherapy protocol.

CONTROL COHORT: Seven cats entered the study during the enrollment period, their characteristics are summarized in table 9. All but a Norwegian cat where Domestic Short Hair cats, three were females and four were males, age ranged from 5 to 13 years. All the owners of these patients elected the continuation of chemotherapy despite its declining efficacy.

TOXICITY: Regarding the cats, gastrointestinal side effects were limited to mild anorexia in one cat while they were not noted in the remaining six. Systemic toxycoses were limited to one cat that experienced a severe neutropenia (grade 3) leading to infection (grade 3) that required hospitalization and antibiotic therapy. Again, the control group patients had a much worse tolerance to the therapy due to progressive disease.

EFFICACY: Six cats benefited with variable degrees of response from the therapy. Four cats showed tumor response ( $2 \mathrm{CR}, 2 \mathrm{PR}$ ), two cats had stabilization of the disease and one was a non responder. The complete responders were a cat with an aggressive lymphoma that had spread to the pancreas, the other was a cat with 
Table 6 Characteristics and outcome of canine patients treated with pump inhibitors and chemotherapy

\begin{tabular}{|c|c|c|c|c|c|}
\hline PATIENT & AGE & TUMOR & PREV. TREATMENT & THERAPY & OUTCOME (MONTHS) \\
\hline GREAT DANE & 10 & $\begin{array}{c}\text { SPLENIC } \\
\text { HSA }\end{array}$ & $\begin{array}{c}\text { SURGERY } \\
\text { METRONOMIC }\end{array}$ & METRONOMIC & CR 3 \\
\hline WHWT & 8 & LSA & $\begin{array}{l}\text { MADISON } \\
\text { MOPP }\end{array}$ & MOPP & CR 12 \\
\hline BULL MAST. & 11 & ALL & $\begin{array}{l}\text { MADISON } \\
\text { MOPP }\end{array}$ & MOPP & CR 3 \\
\hline WHWT & 8 & LSA & $\begin{array}{l}\text { MADISON } \\
\text { MOPP }\end{array}$ & MOPP & CR 8 \\
\hline ROTTW. & 6 & LSA & $\begin{array}{l}\text { MADISON } \\
\text { MOPP }\end{array}$ & MOPP & CR 3 \\
\hline BOXER & 8 & LSA & $\begin{array}{l}\text { MADISON } \\
\text { MOPP }\end{array}$ & MOPP & CR 7 \\
\hline BOXER & 9 & LSA & $\begin{array}{l}\text { MADISON } \\
\text { MOPP }\end{array}$ & MOPP & CR 5 \\
\hline DOGO & 10 & LSA & $\begin{array}{l}\text { MADISON } \\
\text { MOPP }\end{array}$ & MOPP & PR 3 \\
\hline WHWT & 10 & LSA & $\begin{array}{l}\text { MADISON } \\
\text { MOPP }\end{array}$ & MOPP & $P D$ \\
\hline BOXER & 10 & LSA & $\begin{array}{l}\text { COP } \\
\text { MOPP }\end{array}$ & MOPP & CR5+ \\
\hline LABRADOR & 8 & LSA & $\begin{array}{l}\text { COP } \\
\text { MOPP }\end{array}$ & MOPP & CR5+ \\
\hline BULL DOG & 10 & SKIN LSA & $\begin{array}{l}\text { MADISON } \\
\text { MOPP }\end{array}$ & MITOXANTRONE & CR5+ \\
\hline POODLE & 12 & LSA & $\begin{array}{l}\text { COP } \\
\text { MOPP }\end{array}$ & MOPP & DISCONTINUED \\
\hline SETTER & 14 & ORAL SCC & MITOXANTRONE & MITOXANTRONE & DISCONTINUED \\
\hline MIXED & 11 & NASAL CA & MITOXANTRONE & MITOXANTRONE & PR 3+ \\
\hline MIXED & 10 & OSA & BIOPSY & CLODRONATE & PR 7 \\
\hline MIXED & 11 & OSA & BIOPSY & CLODRONATE & PR 11 \\
\hline SCHNAUTZER & 9 & OSA & BIOPSY & CLODRONATE & DISCONTINUED \\
\hline MIXED & 15 & $\begin{array}{c}\text { TCC } \\
\text { BLADDER }\end{array}$ & PIROXICAM & PIROXICAM & SD 7+ \\
\hline BEAGLE & 12 & $\begin{array}{c}\text { TCC } \\
\text { BLADDER }\end{array}$ & $\begin{array}{c}\text { SURGERY } \\
\text { MITOXANTRONE }\end{array}$ & MITOXANTRONE & CR 2+ \\
\hline ROTTWEILER & 5 & MELANOMA & $\begin{array}{c}\text { SURGERY } \\
\text { CARBOPLATIN }\end{array}$ & CARBOPLATIN & NED $5+$ \\
\hline MIXED & 10 & $\begin{array}{l}\text { MAMMARY } \\
\text { CA }\end{array}$ & $\begin{array}{c}\text { SURGERY } \\
\text { MITOXANTRONE }\end{array}$ & MITOXANTRONE & NED $5+$ \\
\hline MIXED & 10 & $\begin{array}{l}\text { MAMMARY } \\
\text { CA }\end{array}$ & $\begin{array}{l}\text { CARBOPLATIN } \\
\text { DOXORUBICIN }\end{array}$ & MITOXANTRONE & PR 9+ \\
\hline MIXED & 11 & FSA & SURGERY, ECT & MITOXANTRONE & NED 3+ \\
\hline MIXED & 12 & $\begin{array}{l}\text { MAMMARY } \\
\text { CA }\end{array}$ & $\begin{array}{c}\text { SURGERY } \\
\text { MITOXANTRONE }\end{array}$ & MITOXANTRONE & NED 4+ \\
\hline GERMAN & 8 & MAMMARY & SURGERY & MITOXANTRONE & NED 4+ \\
\hline SHEPHERD & & CA & MITOXANTRONE & & \\
\hline HUSKY & 13 & MAMMARY & SURGERY & MITOXANTRONE & NED 5+ \\
\hline
\end{tabular}

Abbreviations: ALL: acute lymphocytic leukemia; CA: carcinoma; CA.SA: carcinosarcoma; COP: cyclophosphamide, oncovin (vincristine), prednisone; ECT: electrochemotherapy; FSA: fibrosarcoma; HSA: hemangiosarcoma; LSA: lymphosarcoma; MOPP: mechlorethamine, oncovin (vincristine), prednisone, procarbazine; OSA: osteosarcoma; SCC: squamous cell carcinoma, WHWT: west highland white terrier. +: still alive.

Drugs schedule: doxorubicin $30 \mathrm{mg} / \mathrm{m}^{2}$ every 21 days (pending hematological, cardiac and renal evaluation) up to 6 doses, carboplatin $300 \mathrm{mg} / \mathrm{m}^{2}$ every 21 days, mitoxantrone $6 \mathrm{mg} / \mathrm{m}^{2}$ every 21 days. For Madison and MOPP protocols see table 4 and 5 
Table 7 Characteristics and outcome of canine patients treated with chemotherapy alone for refractory cancers

\begin{tabular}{|c|c|c|c|c|c|}
\hline PATIENT & AGE & TUMOR & $\begin{array}{c}\text { PREV. } \\
\text { TREATMENT }\end{array}$ & THERAPY & $\begin{array}{l}\text { OUTCOME } \\
\text { (MONTHS) }\end{array}$ \\
\hline MIXED & 11 & LSA & $\begin{array}{l}\text { MADISON + } \\
\text { MOPP }\end{array}$ & MADISON & PD 1 \\
\hline SETTER & 6 & ALL & $\begin{array}{l}\text { MADISON + } \\
\text { MOPP }\end{array}$ & MADISON & PD 1 \\
\hline BOXER & 9 & $\begin{array}{c}\text { SKIN } \\
\text { CARCINOMA }\end{array}$ & $\begin{array}{l}\text { DOXORUBICIN } \\
\text { CARBOPLATIN }\end{array}$ & CARBOPLATIN & PR 2 \\
\hline WHWT & 8 & LSA & $\begin{array}{l}\text { MADISON + } \\
\text { MOPP }\end{array}$ & MADISON & PR 1 \\
\hline ROTTW & 7 & LSA & $\begin{array}{l}\text { MADISON + } \\
\text { MOPP }\end{array}$ & MADISON & PR 3 \\
\hline GERMAN & 9 & LSA & $\begin{array}{l}\text { MADISON + } \\
\text { MOPP }\end{array}$ & MADISON & PD 1 \\
\hline SHEPHERD & & & MOPP & & \\
\hline LABRADOR & 9 & LSA & $\begin{array}{l}\text { MADISON + } \\
\text { MOPP }\end{array}$ & MOPP & PD 2 \\
\hline MIXED & 10 & $\begin{array}{l}\text { MAMMARY } \\
\text { CARCINOMA }\end{array}$ & $\begin{array}{l}\text { DOXORUBICIN } \\
\text { CARBOPLATIN }\end{array}$ & DOXORUBICIN & PR 1 \\
\hline DOGO & 10 & LIPOSARCOMA & $\begin{array}{l}\text { DOXORUBICIN } \\
\text { CARBOPLATIN }\end{array}$ & CARBOPLATIN & PD 1 \\
\hline MIXED & 10 & $\begin{array}{l}\text { MAMMARY } \\
\text { CARCINOMA }\end{array}$ & $\begin{array}{l}\text { DOXORUBICIN } \\
\text { CARBOPLATIN }\end{array}$ & CARBOPLATIN & PR 2 \\
\hline
\end{tabular}

Abbreviations: ALL: acute lymphocytic leukemia; LSA: lymphosarcoma; MOPP: mechlorethamine, oncovin (vincristine), prednisone, procarbazine; WHWT: west highland white terrier.

Drugs schedule: doxorubicin $30 \mathrm{mg} / \mathrm{m}^{2}$ every 21 days (pending hematological, cardiac and renal evaluation) up to 6 doses, carboplatin $210 \mathrm{mg} / \mathrm{m}^{2}$ every 21 days, mitoxantrone $6 \mathrm{mg} / \mathrm{m}^{2}$ every 21 days. For Madison and MOPP protocols see table 4 and 5 .

oral squamous cell carcinoma. Figure 2 shows the regression of the pancreatic dissemination in the lymphoma patients. The partial responders were a cat with nasal lymphoma and a cat with mammary carcinoma. Interestingly, the two cats with oral squamous cell carcinoma that had stabilization of their disease showed a significant improvement of their quality of life, in terms of decreased bleeding, activity level, interaction with the owners, improved grooming and increased appetite. In

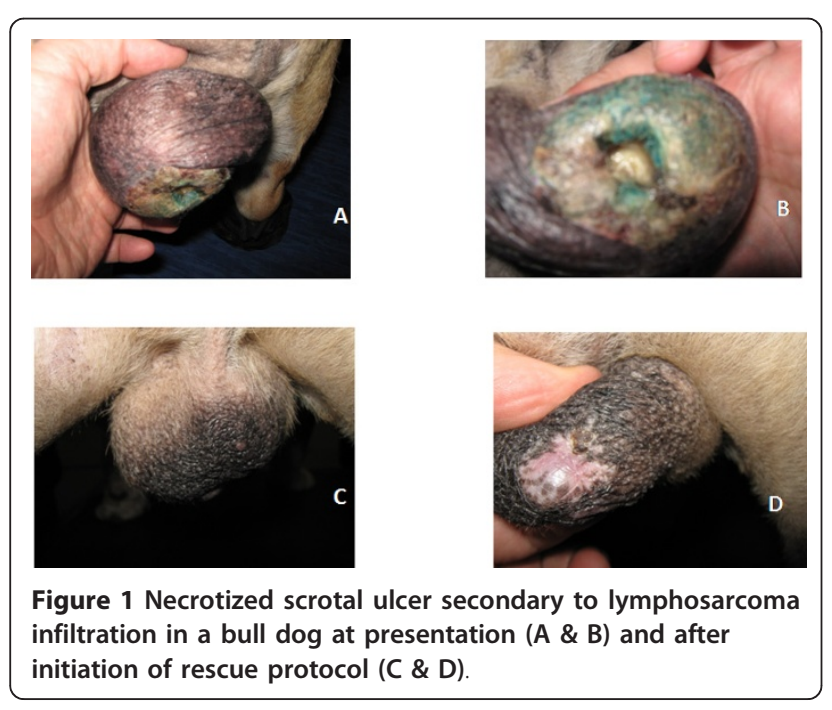

terms of performance, they moved from a grade 3 to a grade 1 Karnofsky status, mostly due to a significantly decreased tumor induced pain. Again, the response rate in the control group was much smaller with only two control cats (one with a soft tissue sarcoma and the other with lymphoma) experiencing a brief partial response lasting two months during the therapy (see Table 9).

At the time of writing a total of 15 patients (12 dogs and 3 cats) are still alive and periodically monitored leading to a survival rate of $44.4 \%$ and $42.8 \%$, respectively. Questioning the owners regarding their degree of satisfaction with the outcome of the therapy yielded a total of $85 \%$ of appreciation that ranged from "moderate" to "enthusiastic". The major cause of complain being the gastrointestinal side effects (specifically the flatulence) experienced by some dogs rather than the degree of tumor response.

\section{Discussion}

From a strictly chemical evaluation of proton pump inhibitors, it is conceivable that being pro-drugs needing acidity to be transformed in the active drug [39], they might be specifically active in the acidic tumor environments. Some reports inferred that metastatic tumors are more acidic then primary tumors, but also that solid tumors, either carcinoma or melanomas or sarcomas, 
Table 8 Characteristics and outcome of feline patients treated with pump inhibitors and chemotherapy

\begin{tabular}{|c|c|c|c|c|c|}
\hline PATIENT & AGE & TUMOR & $\begin{array}{c}\text { PREV. } \\
\text { TREATMENT }\end{array}$ & THERAPY & $\begin{array}{l}\text { OUTCOME } \\
\text { (MONTHS) }\end{array}$ \\
\hline DSH & 10 & $\begin{array}{c}\text { BREAST } \\
\text { CARCINOMA }\end{array}$ & $\begin{array}{c}\text { SURGERY } \\
\text { MITOXANTRONE } \\
\text { PD }\end{array}$ & MITOXANTRONE & PR 4 \\
\hline DSH & 12 & ORAL SCC & $\begin{array}{c}\text { MITOXANTRONE } \\
\text { PD }\end{array}$ & MITOXANTRONE & SD 2 \\
\hline DSH & 10 & ORAL SCC & $\begin{array}{c}\text { SURGERY } \\
\text { MITOXANTRONE } \\
\text { PD }\end{array}$ & MITOXANTRONE & CR 5+ \\
\hline DSH & 12 & ORAL SCC & $\begin{array}{c}\text { BIOPSY } \\
\text { MITOXANTRONE } \\
\text { PD }\end{array}$ & MITOXANTRONE & SD 6 \\
\hline DSH & 12 & LSA & $\begin{array}{c}\text { MOPP } \\
\times 3 \text { months } \\
\end{array}$ & MOPP & CR 6+ \\
\hline DSH & 8 & NASAL LSA & $\begin{array}{c}\text { MOPP } \\
\text { PD }\end{array}$ & MOPP & PR 3+ \\
\hline DSH & 7 & FSA & $\begin{array}{c}\text { SURGERY, } \\
\text { ECT } \times 2, \\
\text { CARBOPLATIN } \\
\times 2 \\
\text { MITOXANTRONE } \\
\times 2\end{array}$ & MITOXANTRONE & $P D$ \\
\hline
\end{tabular}

Abbreviations: DSH: domestic short hair; ECT: electrochemotherapy; FSA: fibrosarcoma; LSA: lymphosarcoma; MOPP: mechlorethamine, oncovin (vincristine), prednisone, procarbazine; SCC: squamous cell carcinoma. +: still alive.

Drugs schedule: doxorubicin $30 \mathrm{mg} / \mathrm{m}^{2}$ every 21 days (pending hematological, cardiac and renal evaluation) up to 6 doses, carboplatin $210 \mathrm{mg} / \mathrm{m}^{2}$ every 21 days, mitoxantrone $6 \mathrm{mg} / \mathrm{m}^{2}$ every 21 days. For MOPP protocol see table 4 and 5 .

are more acidic than systemic tumors (i.e. leukemia) [40]. Therefore, it can be speculated that proton pump inhibitors might be more active against very malignant, often entirely unresponsive to current therapies, tumors. These observations are at least partially contradicted by our findings since in both PPI cohorts we observed extended responses ( $>6$ months) in patients affected by solid tumors as well as in patients with hematological malignancies. In particular we found intriguing the consistent responses obtained both in canine and feline lymphoma patients that had shown a significant refractoriness to standard multi-drug protocols. Pooling together dogs and cats with lymphoma 8 patients out of 14 (57\%) had responses in excess of 5 months. When examining the outcome of patients with advanced solid tumors, we observed a broad spectrum of tumors

Table 9 Characteristics and outcome of feline patients treated chemotherapy alone for chemoresistant cancers

\begin{tabular}{|c|c|c|c|c|c|}
\hline PATIENT & AGE & TUMOR & $\begin{array}{c}\text { PREV. } \\
\text { TREATMENT }\end{array}$ & THERAPY & $\begin{array}{l}\text { OUTCOME } \\
\text { (MONTHS) }\end{array}$ \\
\hline DSH & 10 & $\begin{array}{c}\text { BREAST } \\
\text { CARCINOMA }\end{array}$ & $\begin{array}{l}\text { DOXORUBICIN } \\
\text { CARBOPLATIN }\end{array}$ & CARBOPLATIN & PD 1 \\
\hline $\mathrm{DSH}$ & 12 & FSA & CARBOPLATIN & CARBOPLATIN & PR 2 \\
\hline DSH & 10 & ORAL SCC & $\begin{array}{l}\text { MITOXANTRONE } \\
\text { CARBOPLATIN }\end{array}$ & MITOXANTRONE & PD 1 \\
\hline $\mathrm{DSH}$ & 12 & ORAL FSA & $\begin{array}{l}\text { DOXORUBICIN } \\
\text { CARBOPLATIN }\end{array}$ & CARBOPLATIN & PD 1 \\
\hline $\mathrm{DSH}$ & 12 & LSA & $\begin{array}{l}\text { MADISON } \\
\text { MOPP }\end{array}$ & MOPP & PR 2 \\
\hline DSH & 7 & FSA & $\begin{array}{c}\text { SURGERY, } \\
\text { DOXORUBICIN } \\
\text { CARBOPLATIN }\end{array}$ & CARBOPLATIN & PD 1 \\
\hline NORVEGIAN & 7 & LSA & $\begin{array}{l}\text { MADISON } \\
\text { MOPP }\end{array}$ & MOPP & PD 2 \\
\hline
\end{tabular}

Abbreviations: DSH: domestic short hair; FSA: fibrosarcoma; LSA: lymphosarcoma; MOPP: mechlorethamine, oncovin (vincristine), prednisone, procarbazine; SCC: squamous cell carcinoma. + : still alive.

Drugs schedule: doxorubicin $30 \mathrm{mg} / \mathrm{m}^{2}$ every 21 days (pending hematological, cardiac and renal evaluation) up to 6 doses, carboplatin $210 \mathrm{mg} / \mathrm{m}^{2}$ every 21 days, mitoxantrone $6 \mathrm{mg} / \mathrm{m}^{2}$ every 21 days. For Madison and MOPP protocols see table 4 and 5 . 


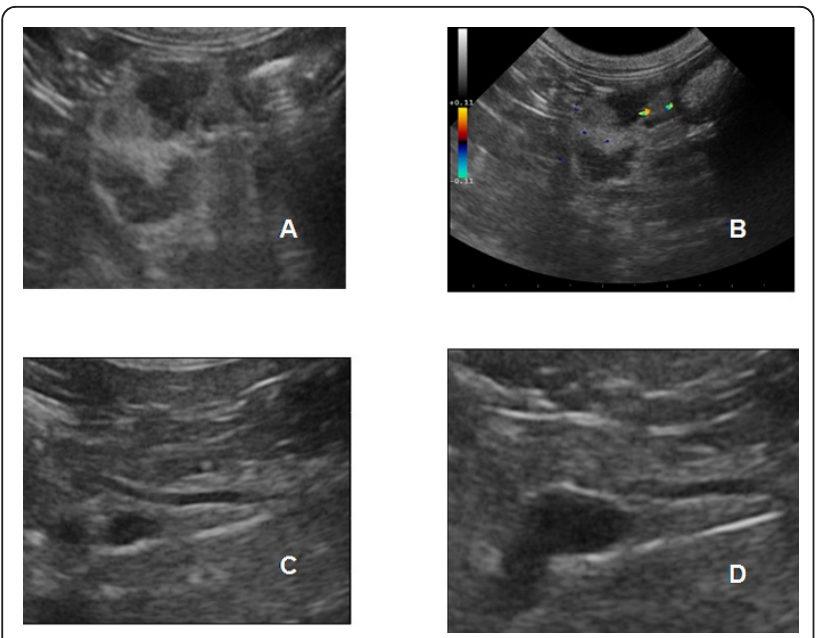

Figure 2 Lymphosarcoma nodules in the pancreas of a cat, diagnosed by fine needle aspiration with ultrasonographic guidance. Ultrasonographic appearance of pancreatic lesions at presentation (A \& B) and after initiation of rescue protocol (C \& D).

vulnerable to our novel strategy. Among them, two of our canine responders suffered neoplasms that are usually refractory to current treatments, including a spinal osteosarcoma and a metastatic anal sac carcinoma. Sarcomas have been shown to be clearly acidic, also by their ability to capture Acridine Orange [41-43]. However, also metastatic neoplasms are particularly acidic as has been shown for human melanomas, that thrive in particularly acidic microenvironments, as compared to primary tumors [27]. In our study, the patient affected by melanoma, showed responsiveness for the treatment of gross disease, being consistent with the observation that acidic condition increases susceptibility of metastatic melanoma cells to proton pump inhibitors [27]. We have showed a dramatic decrease of pain in dogs with osteosarcoma and in cats affected by oral squamous cell carcinoma invading the maxilla or the mandible, following clinical response to the treatment with lansoprazole. This stabilization of tumor mass led to palliation of bone cancer pain, resulting in improved quality of life as shown by increased activity levels, improved grooming and feeding ability, and weight gain, as well. Modulation of tumor microenvironment $\mathrm{pH}$ may be postulated for pain control as well [44], but it is conceivable that a general acidosis is involved in advanced cancer, contributing to the establishment of the typical cachexia of cancer patients [45]. These data are further substantiated by comparing the quality of life of our PPI cohorts with that of controls that showed progressive weight loss, decreased appetite, lower tolerance to chemotherapy (as shown by worse hematological and gastrointestinal toxicities) and the general tendency to move toward higher Karnowski levels. Bone cancer induces bone lysis and remodeling leading to mechanical bone deformation and inducing local tissue acidosis, as well, which in turn may activate pain receptors through several molecular mechanisms, particularly by activation of the capsaicin receptor (transient receptor potential vanilloid, TRPV1) [46,47]. Compelling evidence has shown that TRPV1 is a crucial signal molecule in the development of physiological and pathological pain [46]. In fact, it has been shown that the reduction of $\mathrm{pH}$ may induce both osteoclast-mediated bone reabsorption, with direct stimulation of nociceptive receptors, and the switch-on signal transmission by acid-sensing channels such as TRPV 1 located on pain-sensing neurons [46-48]. The high response rate observed in this study is extremely promising, considering that most patients suffered advanced cancers refractory to chemotherapy. This PPI-induced response to anti-tumor therapy provides the proof of concept that inhibition of the proton pump may represent a new approach in the struggle against cancer. The mechanisms of this efficacy lay in both the improvement of chemotherapy by countering the acid mileu of the tumors [26], but also the induction of tumor self-digestion triggered by the increased cytoplasmic protonation [27-31].

\section{Conclusions}

The results obtained in pets with spontaneous neoplasms will be instrumental for the planning of further investigations to be pursued in humans, thus hopefully shortening the time frame necessary for the adoption of this approach in clinical oncology $[49,50]$. Our data are particularly comforting for patients with hematological malignancies, due to the relatively high number of enrolled canine and feline patients. The data on solid tumors response, albeit promising need to be further substantiated by the enrollment of other patients. Studies are currently ongoing for several specific solid tumor histotypes that will be instrumental for the standardization of the PPI protocols.

Extending the number of patients treated with this new approach is needed to further support the result of this study and to identify both the more sensitive tumor histotypes and the better PPI and conventional chemotherapy combinations. Prospective studies will be conducted to evaluate the efficacy of PPI administered to non-chemoresistant tumors. Finally, we want to emphasize that this study adds much on the set up of new anti-tumor therapies based on drugs with low cost, minimal toxicity, effective pain palliation and antitumor efficacy.

List of abbreviations

PPI: proton pump inhibitors; TRPV1: transient receptor potential vanilloid. 


\section{Acknowledgements}

This work has been supported by "Grant 2010", by a AiCC Grant, and "PROJECT FIRB/MUR (RBIPO6LCA9-009) Grant"of the Italian Ministry of Health to E.P.S and G.C., and by a FUTURA-onlus Grant to E.P.S. and A.B. and a Second University of Naples Grant to A.B. Finally, this study was supported in part by the Italian Ministry of Health, in part by an Italy-to-China partnership project and by Chemores FP6 European Project.

\section{Author details}

${ }^{1}$ SAFU Department, Regina Elena Cancer Institute, Rome, Italy. ${ }^{2}$ Department of Biochemistry, Second University of Naples, Naples, Italy. ${ }^{3}$ Ambulatorio Veterinario "Le Accademie", Rome, Italy. ${ }^{4}$ Ambulatorio Veterinario "Farnesina", Rome, Italy. ${ }^{5}$ Centro Veterinario Gianicolense, Rome, Italy. ${ }^{6}$ Anti-Tumor Drug Section, Dept. of Drug Research and Medicine Evaluation, National Institute of Health (ISS), Rome, Italy.

\section{Authors' contributions}

EPS, GC and SF conceived the study and participated in its design and coordination and wrote the article; MdB G, SB, FC, GB, IP and FM helped with the clinical management of the patients, $A B$ participated in the design of the study and performed the histopathological analysis. All the authors read and approved the final manuscript.

\section{Competing interests}

The authors declare that they have no competing interests.

Received: 3 December 2011 Accepted: 28 December 2011 Published: 28 December 2011

\section{References}

1. Finbow ME, Harrison MA: The vacuolar H+-ATPase: a universal proton pump of eukaryotes. Biochem J 1997, 324:697-712.

2. Forgac M: Vacuolar ATPases: rotary proton pumps in physiology and pathophysiology. Nat Rev Mol Cell Biol 2007, 8:917-929.

3. Cipriano DJ, Wang Y, Bond S, Hinton A, Jefferies KC, Qi J, Forgac M: Structure and regulation of the vacuolar ATPases. Biochim Biophys Acta 2008, 1777:599-604.

4. Jefferies KC, Cipriano DJ, Forgac M: Function, structure and regulation of the vacuolar (H+)-ATPases. Arch Biochem Biophys 2008, 476:33-42.

5. Sautin YY, Lu M, Gaugler A, Zhang L, Gluck SL: Phosphatidylinositol 3kinase-mediated effects of glucose on vacuolar H+-ATPase assembly, translocation, and acidification of intracellular compartments in renal epithelial cells. Mol Cell Biol 2005, 25:575-589.

6. Trombetta ES, Ebersold M, Garrett W, Pypaert M, Mellman I: Activation of lysosomal function during dendritic cell maturation. Science 2003, 299:1400-1403.

7. Feng $Y$, Forgac $M$ : A novel mechanism for regulation of vacuolar acidification. J Biol Chem 1992, 267:19769-19772.

8. Feng Y, Forgac M: Cysteine 254 of the $73-\mathrm{kDa}$ A subunit is responsible for inhibition of the coated vesicle $(\mathrm{H}+$ )-ATPase upon modification by sulfhydryl reagents. J Biol Chem 1992, 267:5817-5822.

9. Feng $Y$, Forgac $\mathrm{M}$ : Inhibition of vacuolar $\mathrm{H}(+)$-ATPase by disulfide bond formation between cysteine 254 and cysteine 532 in subunit A. J Biol Chem 1994, 269:13224-13230.

10. Forgac M: The vacuolar H+-ATPase of clathrin-coated vesicles is reversibly inhibited by Snitrosoglutathione. J Biol Chem 1999, 274:301-1305

11. XU T, Forgac M: Subunit D (Vma8p) of the yeast vacuolar H+-ATPase plays a role in coupling of proton transport and ATP hydrolysis. J Biol Chem 2000, 275:22075-22081.

12. Kawasaki-Nishi S, Bowers K, Nishi T, Forgac M, Stevens TH: The aminoterminal domain of the vacuolar proton-translocating ATPase a subunit controls targeting and in vivo dissociation, and the carboxyl-terminal domain affects coupling of proton transport and ATP hydrolysis. J Biol Chem 2001, 276:47411-47420.

13. Saitoh O, Wang WC, Lotan R, Fukuda M: Differential glycosylation and cell surface expression of lysosomal membrane glycoproteins in sublines of a human colon cancer exhibiting distinct metastatic potentials. J Biol Chem 1992, 267:5700-5711.
14. Glunde K, Guggino SE, Solaiyappan M, Pathak AP, Ichikawa Y, Bhujwalla ZM: Extracellular acidification alters lysosomal trafficking in human breast cancer cells. Neoplasia 2003, 5:533-545.

15. Gatenby RA, Gillies RJ: Why do cancers have high aerobic glycolysis? Nat Rev Cancer 2004, 4:891-899.

16. Fais $\mathrm{S}$, De Milito A, You H, Qin W: Targeting vacuolar $\mathrm{H}^{+}$-ATPases as a new strategy against cancer. Cancer Res 2007, 67:10627-10630.

17. Nishi T, Forgac M: The vacuolar $\left(\mathrm{H}^{+}\right)$-ATPases nature's most versatile proton pumps. Nat Rev Mol Cell Biol 2002, 3:94-103.

18. Martinez-Zaguilan R, Lynch RM, Martinez GM, Gillies RJ: Vacuolar-type H (+)-ATPases are functionally expressed in plasma membranes of human tumor cells. Am J Physiol 1993, 265:1015-29.

19. Lu X, Qin W, Li J, Tan N, Pan D, Zhang H, Xie L, Yao G, Shu H, Yao M, Wan D, Gu J, Yang S: The growth and metastasis of human hepatocellular carcinoma xenografts are inhibited by small interfering RNA targeting to the subunit ATP6L of proton pump. Cancer Res 2005, 65:6843-6849.

20. Mahoney BP, Raghunand N, Bagget B, Gillies RJ: Tumor acidity, ione trapping and chemotherapeutics I. Acid pH effects the distribution of chemotherapeutic agents in vitro. Biochem Pharmacol 2003, 66:1207-1218.

21. Simon S, Roy D, Schindler M: Intracellular Ph and the control of multidrug resistance. Proc Nat Acad Sci USA 1993, 91:1128-1132.

22. Raghunand N, Mahoney BP, Gillies RJ: Tumor acidity, ion trapping and chemotherapeutics. II. pH-dependent partition coefficients predict importance of ion trapping on pharmacokinetics of weakly basic chemotherapeutic agents. BiochemPharmacol 2003, 66:1219-1229.

23. Martínez-Zaguilán R, Raghunand N, Lynch RM, Bellamy W, Martinez GM, Rojas B, Smith D, Dalton WS, Gillies RJ: pH and drug resistance. I. Functional expression of plasmalemmal V-type H+-ATPase in drugresistant human breast carcinoma cell lines. Biochem Pharmacol 1999, 57:1037-1046.

24. Raghunand N, Martínez-Zaguilán R, Wright SH, Gillies RJ: $\mathrm{pH}$ and drug resistance. II. Turnover of acidic vesicles and resistance to weakly basic chemotherapeutic drugs. Biochem Pharmacol 1999, 57:1047-1058.

25. Bobichon H, Colin M, Depierreux C, Liautaud-Roger F, Jardillier JC: Ultrastructural changes related to multidrug resistance in CEM cells: role of cytoplasmic vesicles in drug exclusion. J Exp Ther Oncol 1996, 1:49-61.

26. Luciani F, Spada M, De Milito A, Molinari A, Rivoltini L, Montinaro A, Marra M, Lugini L, Logozzi M, Lozupone F, Federici C, lessi E, Parmiani G, Arancia G, Belardelli F, Fais S: Effect of proton pump inhibitor pretreatment on resistance of solid tumors to cytotoxic drugs. J Natl Cancer Inst 2004, 96:1702-1713.

27. De Milito A, Canese R, Marino ML, Borghi M, lero M, Villa A, Venturi $G$, Lozupone F, lessi E, Logozzi M, Mina PD, Santinami M, Rodolfo M, Podo F, Rivoltini L, Fais S: pH-dependent antitumor activity of proton pump inhibitors against human melanoma is mediated by inhibition of tumor acidity. Int J Cancer 2010, 127:207-19.

28. Murakami T, Shibuya I, Ise T, Chen ZS, Akiyama S, Nakagawa M, Izumi H, Nakamura T, Matsuo K, Yamada Y, Kohno K: Elevated expression of vacuolar proton pump genes and cellular $\mathrm{PH}$ in cisplatin resistance. Int $\mathrm{J}$ Cancer 2001, 93:869-874.

29. Torigoe T, Izumi H, Ishiguchi $H$, Uramoto H, Murakami T, Ise T, Yoshida $Y$, Tanabe M, Nomoto M, Itoh H, Kohno K: Enhanced expression of the human vacuolar $\mathrm{H}+$-ATPase $\mathrm{c}$ subunit gene (ATP6L) in response to anticancer agents. J Biol Chem 2002, 277:36534-36543.

30. Torigoe T, Izumi H, Yoshida Y, Ishiguchi H, Okamoto T, Itoh H, Kohno K: Low pH enhances Sp1 DNA binding activity and interaction with TBP. Nucleic Acids Res 2003, 31:4523-4530.

31. De Milito A, lessi E, Logozzi M, Lozupone F, Spada M, Marino ML, Federici C, Perdicchio M, Matarrese P, Lugini L, Nilsson A, Fais S: Proton pump inhibitors induce apoptosis of human B-cell tumors through a caspaseindependent mechanism involving reactive oxygen species. Cancer Res 2007, 67:5408-17.

32. Thamm DH, Vail DM: Mast cell tumors. In Small Animal Clinical Oncology.. 4 edition. Edited by: Withrow SJ, MacEwen EG. Philadelphia, PA: WB Saunders Co; 2007:402-424.

33. Brooks D, Watson GL: Omeprazole in a dog with gastrinoma. J Vet Intern Med 1997, 11:379-381.

34. Fukushima R, Ichikawa K, Hirabayashi M, Yamagami T, Koyama H, Hirose $H$, Uchino T: A case of canine gastrinoma. J Vet Med Sci 2004, 66:993-995. 
35. Hughes SM: Canine gastrinoma: a case study and literature review of therapeutic options. N Z Vet J 2006, 54:242-247.

36. Ward CR: Gastrointestinal endocrine disease.Edited by: Ettinger SJ, Feldman EC. Textbook of Veterinary Internal Medicine; , Seventh 2010:1862-1865, Saunders, St. Louis.

37. Klohs WD, Steinkampf RW: The effect of lysosomotropic agents and secretory inhibitors on anthracycline retention and activity in multiple drug-resistant cells. Mol Pharmacol 1988, 34:180-185.

38. Simon SM, Schindler M: Cell biological mechanisms of multidrug resistance in tumors. Proc Natl Acad Sci USA 1994, 91:3497-3504.

39. Coruzzi G, Adami M, Bertaccini G: Gastric antisecretory activity of lansoprazole in different experimental models: comparison with omeprazole. Gen Pharmacol 1995, 26:1027-1032.

40. Spugnini EP, Citro G, Fais S: Proton pump inhibitors as anti vacuolarATPases drugs: a novel anticancer strategy. J Exp Clin Cancer Res 2010, 29:44.

41. Matsubara T, Kusuzaki K, Matsumine A, Shintani K, Satonaka H, Uchida A: Acridine orange used for photodynamic therapy accumulates in malignantmusculoskeletal tumors depending on $\mathrm{pH}$ gradient. Anticancer Res 2006, 26:187-193.

42. Kusuzaki K, Murata H, Matsubara T, Satonaka H, Wakabayashi T, Matsumine A, Uchida A: Acridine orange could be an innovative anticancer agent under photon energy. In Vivo 2007, 21:205-214.

43. Fais S: Proton pump inhibitor-induced tumour cell death by inhibition of a detoxification mechanism. J Intern Med 2010, 267(5):515-25.

44. Abraham J, Ross E, Klickovich RJ: Cancer-related bone pain.Edited by: Ballantyne J, Fishman SM, Rathmell JP. Bonica's management of pain. Lippincott Williams , 4 2009:629-654.

45. Drochioiu G: Chronic metabolic acidosis may be the cause of cachexia: body fluid $\mathrm{pH}$ correction may be an effective therapy. Med Hypotheses 2008, 70:1167-73.

46. Pan HL, Zhang YQ, Zhao ZQ: Involvement of lysophosphatidic acid in bone cancer pain by potentiation of TRPV1 via PKC $\varepsilon$ pathway in dorsal root ganglion neurons. Mol Pain 2010, 6:85.

47. Okumura R, Shima K, Muramatsu T, Nakagawa K, Shimono M, Suzuki T, Magloire H, Shibukawa Y: The odontoblast as a sensory receptor cell? The expression of TRPV1 (VR-1) channels. Arch Histol Cytol 2005, 68:251-257.

48. Roodman GD: Biology of Osteoclast Activation in Cancer. J Clin Oncol 2001, 19:3562-3571.

49. Porrello A, Cardelli P, Spugnini EP: Pet models in cancer research: general principles. J Exp Clin Canc Res 2004, 2:5-17.

50. Porrello A, Cardelli P, Spugnini EP: Oncology of companion animals as a model for humans: an overview of tumor histotypes. J Exp Clin Cancer Res 2006, 25:97-106.

doi:10.1186/1479-5876-9-221

Cite this article as: Spugnini et al:: Lansoprazole as a rescue agent in chemoresistant tumors: a phase I/II study in companion animals with spontaneously occurring tumors. Journal of Translational Medicine 2011 9:221.

\section{Submit your next manuscript to BioMed Central and take full advantage of:}

- Convenient online submission

- Thorough peer review

- No space constraints or color figure charges

- Immediate publication on acceptance

- Inclusion in PubMed, CAS, Scopus and Google Scholar

- Research which is freely available for redistribution 